\title{
Development of the reading culture in pre- service teachers amid digitalization of education
}

\author{
Zinaida Kekeeva $^{1, *}$, Svetlana Darzhinova ${ }^{1}$, Elmira Abdiraimova ${ }^{2}$ \\ ${ }^{1}$ Kalmyk State University named after B. B. Gorodovikov, 11, Pushkina Street, Elista, 358000, Russia \\ ${ }^{2}$ West Kazakhstan State University named after M. Utemisov, 162, Dostyk-Druzhby Avenue, Uralsk, \\ 090000, Kazakhstan
}

\begin{abstract}
The article deals with the problem of developing a pre-service teacher's reading culture as a way to build professional competence in the context of digital education in the Republic of Kazakhstan. The results of the questionnaire demonstrated that more than a half of the study pool of pre-service teachers made a conscious choice of a teaching profession, and the same number indicated difficulties in organizing their independent work with different texts. The results have also shown that around $90 \%$ of preservice teachers do not consider books as a professional tool, and indicated major factors impeding reading: the Internet; difficulties in linear and nonlinear reading; lack of attention; financial struggles. The obtained results of the pedagogical experiment, carried out at the West Kazakhstan State University named after $M$. Utemisov suggest that using pedagogical experiment, with its collaborative workshops in conjunction with the university library, problem-based tasks, and educational role plays, afford beneficial ways of developing the reading culture among pre-service teachers. The materials of the article can be used in the context of higher education for delivering courses on digital pedagogy, as well as in organizing the teaching practice of students at school, etc.
\end{abstract}

\section{Introduction}

Due to the huge flow of information, humanity has been experiencing extreme mental stress, which leads to reduction in the information received, its fragmentary perception and disappearance of the phase of thinking [1], absence of comprehension and consolidation of the information received, which are important to the reading process [2]. As a result, all of these factors direct to a general decline in the reading culture. One of the pressing challenges in the professional university training is the advancement of the reading competence in future, or pre-service teachers.

It should be noted that digital education has been dynamically developing in the world's educational space, largely at schools and universities, however, it has been a factor, which reduces the interest in reading and decreases the reading culture in those contexts [3]. To address this problem, the Republic of Kazakhstan, for example, has been actively implementing the state program "Digital Kazakhstan" [4]. Through this program, schools in

\footnotetext{
*Corresponding author: kekeeva-zo@yandex.ru
} 
Kazakhstan aim at the development of educated, well-mannered, and functionally literate individuals, predominantly through acquaintance with the moral standards of humanity as a whole and the country's nation in particular. Furthermore, since 2013, the schools of the Republic of Kazakhstan have been implementing the educational project entitled as "Kazakhstani Map for Children's Reading" [4]. This project incorporates the study of masterpieces of Kazakh, Russian, and foreign literatures, since reading literature, which belong to the world cultural heritage, contributes to the development of a personality with its system of values, ideals, abilities, and spirit.

However, despite the measures taken, Kazakhstan experiences a sharp decline in the reading interest, followed by a decrease in the level of the reading culture in its population. As a matter of fact, not only Kazakhstan, but also its neighboring countries demonstrate a rapid decline in the number of readers and book admirers [5]. One of the evidences for this are the results of the international research of functional literacy of 15-year-old students PISA. Thus, starting from 2018, there has been a decrease in the reading literacy of Kazakhstani schoolchildren by 40 points [6]. What is more, the problem of establishing the reading culture in teacher's training within the higher education system of the Republic of Kazakhstan has not been sufficiently tackled. But it should be teachers who have to reveal the best examples of the reading culture to their students and be able to demonstrate professional competence in their area. They also have to possess the ability and willingness to study independently, which are directly related to the reading culture as a source of selfeducation and individual development [7].

The "habit of reading" is an integral part of the "reading culture", its core, as it covers the process of reading itself. There is a dialectical unity and mutual influence among these two concepts [8]. The general stock of knowledge affects the perception of literary texts, whereas perception, assimilation of information, and new ways of reading enrich the reading culture, improve analytical and cognitive skills, as well as human intelligence [9]. It should be borne in mind that the concept of the "reading culture" has been forming over centuries, and each cultural epoch introduces "its own vision" of the goals and objectives of reading, experience of communicating with books [10]. These days books and reading as a part of the value system of our modern society are far from the first place [11].

To ensure that in-service teachers transfer the finest model of the reading culture to their students throughout teaching activity, we might need to focus on the development of reading culture in a pre-service teacher. This phenomenon consists of many facets, from the ability to work with digital technologies [12] and technological start-ups [13], to holding critical and creative thinking, showing willingness to self-educate and self-develop during various innovative educational activities [14].

The development of the reading culture in pre-service teachers in the context of digitalization of education is one of the efficient ways of educating creative individuals, enhancing their communication skills, evolving cognitive processes, such as attention, memory, thinking, and intellectual abilities [15].

Taking the above stated premises into consideration, we put the aim of this article as to consider the problem of the development of the reading culture in pre-service teachers in the context of digital higher education in Kazakhstan.

\section{Materials and Methods}

In the reported study, we implemented the analysis of theoretical and psychological and pedagogical literature. From the empirical research methods, we employed observation and questionnaire. For conducting the experimental part of the study, we applied pedagogical experiment alongside methods of mathematical processing of research results. 
This study was conducted between 2016 and 2020 at the pedagogical faculty of the West Kazakhstan State University named by M. Utemisov. We recruited 232 bachelor's degree students of the pedagogical major. We offered the questionnaire to our participants in order to study their motives for choosing the career of a teacher; their learning difficulties; factors that interfere with reading; reading preferences, as well as the role of the reading culture in their professional activities,.

The process of development of the reading culture among pre-service teachers was carried out as a sequence of solving educational problematic situations adjacent to the sphere of real communications of a pre-service teacher. For instance, we brought these situations to the forefront in the course of our pedagogical experiment: (1) situation of reflection and identification of the reading problem; (2) situation of the choice of means taking into account the traditions and conditions of the ethnic environment; (3) situation in the context of business and intersubjective problems, which takes into account their ethnocultural interpretation and forecast of psychological consequences; (4) situation of the implementation of the functions and targets of the reading culture; and finally (5) situation of the choice and implementation of resources, taking into account the current university setting.

Then, using the same method, we gave our special attention to various forms of organizing productive interaction of pre-service teachers with the university library during workshops on the topics "Search for Digital and Non-Digital Information Sources Using Catalogues", "Working with Scientific Texts", etc. In the classroom settings, literary texts from both Russian and Kazakh authors were used, as well as education-related texts, so that pre-service teachers could work on their reading skills and speech development, as well as boost their ability to creatively approach solutions to problems.

We also made use of the problem-based tasks in the pedagogy and psychology courses, so that pre-service teachers were to independently find the necessary and interesting information on the indicated topic or problem from various information sources. The subsequent demonstration of the found and selected material served as a subject of discussion for an entire group. For enhancing public speaking skills in pre-service teachers, they were to complete exercises and tasks based on what they read in order to be efficaciously prepared for their future professional activities. They particularly took part in educational role plays, conversations and discussions, preparation and presentation of lectures, prepared reports and gave talks in front of different audiences.

To illustrate few of the activities, pre-service teachers took an active part in preparing and conducting a scientific event named as "Pedagogical Readings", during which they learned to speak in public, using various ways of presenting their material, attracting their audience's attention, maintaining contact with their audience, etc. Our pool of pre-service teachers was also introduced to the educational role play "How to communicate with schoolchildren?". During the game, the participants had conversations, disputes, discussions on the topic "Reading culture: pros and cons" and the debate "My main book."

\section{Results}

The results of the questionnaire showed that more than $54 \%$ of pre-service teachers of the bachelor's degree program majoring in pedagogy made their conscious choice of a teaching profession and their wish to study at a university, whereas $46 \%$ indicated other goals. Among those goals were plans to enroll in master's programs in other areas upon graduation; desire to get a higher education; having a degree is a fulfilment of the insistence of their parents. $5 \%$ of the respondents noted that they have chosen a teaching profession, since one of their parents is a teacher. More than $50 \%$ of students indicated that they experience difficulties in organizing independent work with different texts and the ability to interpret them in the 
university setting. The results of our questionnaire have also shown that $87 \%$ of pre-service teachers do not perceive books as a professional tool.

$13 \%$ of future teachers like to read books, while almost all of them $(98 \%)$ are demanded by their instructors to read texts in order to prepare for classes. It should be noted that $14 \%$ of respondents enjoy reading, and they read books till the end. Only $20 \%$ of respondents discuss the books they have read with others, e.g., family, friends, and only $5 \%$ of pre-service teachers indicated that reading books contributes to their development of social experience in life.

The main factors hindering their reading are the Internet $-15 \%$, difficulties in constructing texts of various styles and genres using linear and nonlinear reading $-17 \%$, lack of attentive reading skills $-19 \%$, financial struggles $-3 \%$. At the same time, $56 \%$ of respondents prefer to read modern fiction, 30\% - classical literature, 12\% - Kazakh literature.

It should be noted that $49 \%$ of Year 1 students of the bachelor's degree program majoring in pedagogy regularly visit libraries and $76.5 \%$ of Year 2 students recognize the importance of the reading culture in their future professional activity as in-service teachers. The analysis of the research results also revealed that instructors of pre-service teachers do not assign specific tasks to develop reading culture.

The results of the pedagogical experiment are as follows. First, in the course of our collaborative workshops with the university library, pre-service teachers learned to search for information correctly, e.g., by using library catalogues. They managed to work with different scientific texts and understand what text templates are, etc. Such activities were theoretical trainings combined with practical experience, which became useful for preservice teachers in solving reading problems and producing illustrations of reading culture in the educational environment of a university.

Second, problem-based tasks and educational role plays created the environment for the development of creative thinking in pre-service teachers, for their inclusion in professional and creative activities. The tasks, which were offered to pre-service teachers at seminars and practical classes, provided for the development of skills and abilities to transform a text, activate their audience, give peer feedback, operate with various methods of interaction and attracting and retaining attention, etc. In general, we see that the complication of tasks from course to course allowed pre-service teachers to gradually bring up their individual reading culture.

\section{Discussion}

The digitalization of education is being globally introduced into the process and content of professional training of pre-service teachers at a university. However, the reading culture of a future teacher in the context of digitalization of higher education is formed today rather spontaneously, and its state does not correspond to the requirements of our time.

Based on the questionnaire results, we note that pre-service teachers display an interest in the chosen direction, but at the same time they do not always realize the need to maintain their reading culture as the basis for overcoming the lack of knowledge in the learning process and further professional activity. They read little and therefore have insufficient reading skills. At the same time, pre-service teachers observe difficulties in choosing information sources when working with texts in a digital format. In this regard, the success of solving this issue chiefly depends on the level of pre-service teacher's individual reading culture, which should include the skills of an independent work on the development and appropriation of the value-semantic content of information sources.

Reliant on the results from the pedagogical experiment, we acknowledge the fact that conducting collaborative workshops, e.g., with the library, which are related to searching and reading digital and non-digital texts can add up to the reading culture of a pre-service teacher. 
In particular, these activities can improve the ability of pre-service teachers to understand, perceive, influence motivations and behaviors of others, develop an interactive dialogue in the form of user-computer interaction, as well as actively participate in different events by using multimedia technologies.

We also think that the use of problem-based tasks and role play technologies helps to simulate and reproduce various professional situations. When university instructors clarify the situation and conditions of communication, identify possible topics, assess a number of social factors to pre-service teachers, the task of the latter is to pay attention to goals, logic, argumentation, the use of verbal and non-verbal means. This type of tasks contributes to the development of thoughtfulness, tolerance, the ability to conduct a debate, possess selfcontrol, and consider the emotional sensitivity of an interlocutor.

Overall, based on our findings, we suggest that the psychological mechanism for the development of the reading culture in pre-service teachers is the mastery of personal experience in overcoming various contradictions, or conflicts in digital education, and achieving professional competence in solving in-service communication problems.

\section{Conclusion}

The development of the reading culture at a university level in the context of digital education on the example of the Republic of Kazakhstan has shown that reading culture has to be considered as a set of sufficiently formed professional knowledge, reading, organizational skills, abilities for self-control, empathy, culture of verbal and non-verbal interaction. The reading culture needs to be viewed as a personal and professional quality manifested in relations with others, and as an intellectual characteristic of a pre-service teacher, associated with the ability to independently work with various information sources; conducting an exchange of information with other people; management of own behavior and the behavior of others; organization of certain professional activities.

The study confirmed our assumption that it is necessary to develop productive methods of searching and selecting information sources when the reading culture is considered within the university setting as a necessity for pre-service teachers to overcome the lack of knowledge in the learning process and subsequent professional activity.

The conducted research could not solve the entire indicated problem of the reading culture in pre-service teachers, therefore, so as for the topics for further research, we assume the following research strands:

- theoretical foundations of modelling a dynamic and professionally oriented environment in educational settings.

- the role of the reading culture in the process of adaptation of a young teacher in the professional community.

- the reading culture as a tool for socialization and adaptation in a society.

Our findings and their interpretation can be used to develop lectures on the theory and methodology of pre-service teachers' training in particular or higher education pedagogy in general. The reported study can also be helpful for addressing the questions of the advancement of in-service teachers' reading culture in digital education, as well as in the context of working with parents to foster a child's interest in reading and cultivate the reading culture in family education.

\section{References}

1. W. Xie, Journal of Contemporary Educational Research 3(3), 33-37 (2019) https://doi.org/10.26689/jcer.v3i3.693 
2. C. Mills, J. Gregg, R. Bixler, S.K. D’Mello, Human-Computer Interaction, 1-27 (2020) https://doi.org/10.1080/07370024.2020.1716762

3. P. Delgado, C. Vargas, R. Ackerman, L. Salmerón, Educational Research Review 25, 23-38 (2018) https://doi.org/10.1016/j.edurev.2018.09.003

4. E.S. Petrenko, A.L. Shevyakova, Ubiquitous Computing and the Internet of Things: Prerequisites for the Development of ICT (Springer, Cham, 2019) https://doi.org/10.1007/978-3-030-13397-9_91

5. S. Zubaidah, A.D. Corebima, S. Mahanal, International Journal of Instruction 11(2), 4156 (2018) https://doi.org/10.12973/iji.2018.1124a

6. A. Aldashev, A.M. Danzer, The Journal of Development Studies, 1-19 (2020) https://doi.org/10.1080/00220388.2020.1779927

7. A. Türkel, E.E. Özdemir, S. Akbulut, International Journal of Education and Literacy Studies 7(2), 197-210 (2019) https://doi.org/10.7575/aiac.ijels.v.7n.2p.197

8. H. Tonka, S. Bakir, Journal of Educational Issues 6(1), 293-313 (2020) https://doi.org/10.5296/jei.v6i1.16986

9. W. Paulson, The noise of culture: Literary texts in a world of information (Cornell University Press, 2019)

10. Ye.V. Belina, Mezhdunarodnyy nauchno-issledovatel'skiy zhurnal 11(65), 79-81 (2017) https://doi.org/10.23670/IRJ.2017.65.122

11. Yu.P. Melent'yeva, Nauchnyye i tekhnicheskiye biblioteki 4, 76-83 (2019) https://doi.org/10.33186/1027-3689-2019-4-76-83

12. S. Nykvist, M. Mukherjee, Procedia-Social and Behavioral Sciences 217, 851-857 (2016) https://doi.org/10.1016/j.sbspro.2016.02.012

13. M.H. Baturay, Ş. Gökçearslan, F. Ke, International Journal of Technology Enhanced Learning 9(1), 1-13 (2017) https://doi.org/10.1504/IJTEL.2017.084084

14. K.E. Bezukladnikov, B.A. Kruze, Procedia-Social and Behavioral Sciences 200, 393397 (2015) https://doi.org/10.1016/j.sbspro.2015.08.084

15. M. Farías, L. Véliz, Profile Issues in Teachers' Professional Development 21(2), 13-27 (2019) https://doi.org/10.15446/profile.v21n2.75172 